\title{
GEODERMA
}

Geoderma 72 (1996) 149-160

\section{Characteristics and methanogenesis of the Balandra lagoon mangrove soils, Baja California Sur, Mexico}

\author{
L. Giani ${ }^{a}$,Y. Bashan ${ }^{\mathrm{b}}$, G. Holguin ${ }^{\mathrm{b}}$, A. Strangmann ${ }^{\mathrm{a}}$ \\ ${ }^{a}$ Dept. Soil Science, Fb 7, C.u.O. University, P.O. Box 2503, D-261 11 Oldenburg, Germany \\ ${ }^{\mathrm{b}}$ Dept. Microbiology The Center for Biological Research (CIB), P.O. Box 128, La Paz, B.C.S. 23000, Mexico
}

Received 22 September 1995; accepted 1 March 1996

\begin{abstract}
Soil characteristics and methanogenesis were investigated in Fluvisols of the Balandra lagoon mangrove in Baja California, Mexico in March/April 1995.

The grain size distribution was dominated by the silt fraction (54-92\%), sand and clay contents were $6-44 \%$ and $0-19 \%$, respectively. Bulk density was $0.6-1.5 \mathrm{~g} \mathrm{~cm}^{-3}$, the water content $290-690 \mathrm{ml}^{-1}$ and the air content $38-200 \mathrm{ml}^{-1}$. The soils always showed saline conditions $\left(30-70 \mathrm{~g} \mathrm{~kg}^{-1}\right)$, mostly negative redox potentials (down to $-202 \mathrm{mV}$ ), $\mathrm{P}$ contents from 0.8 to $16.0 \mathrm{~g} \mathrm{~kg}^{-1}, \mathrm{C}_{\text {org }}$ contents from $<2$ to $140 \mathrm{~g} \mathrm{~kg}^{-1}$ and neutral $\mathrm{pH}$ values. In one soil the $\mathrm{pH}$ dropped $<2,5$ after peroxide treatment indicating, together with low carbonate/pyrite ratios (mostly <3) sulfidic properties. The relative distribution of the porewater canons was always $74 \% \mathrm{Na}$, $17 \% \mathrm{Mg}, 6 \% \mathrm{Ca}$, and $3 \% \mathrm{~K}$. For the exchangeable and water soluble cation fraction it was $28-59 \% \mathrm{Na}, 22-34 \%$ $\mathrm{Mg}, 12-32 \% \mathrm{Ca}$, and 2-5\% K, with increasing Na- and decreasing Ca-concentrations in the transect from sea to land.

The methane concentrations were mostly lower than $2 \mu \mathrm{M}$. Methane production rates were between 1 and $23 \mathrm{nmol} \mathrm{ml}^{-1} \mathrm{~d}^{-1}$. Methane emission was not detectable. This indicates, that methanogenesis is balanced by methane oxidation processes within the soil. Higher methane concentrations $(33 \mu \mathrm{M})$ and production rates $(100$ $\mathrm{nmol} \mathrm{ml} \mathrm{d}^{-1} \mathrm{~d}^{-1}$ ) in one of the investigated soils were attributed to anthropogenic impact. Consequently, in case of human manipulation the potential of mangrove soils to emit methane seems to be high, thus mangroves are sensitive with respect to methanogenesis.
\end{abstract}

\section{Introduction}

Mangroves are important tropical and subtropical ecosystems in the transition between land and sea. They can be highly productive (Odum and Heald, 1975; Dye and Lasiak, 1986; Robertson, 1986), and export organic matter to the adjacent waters (Twilley, 1985; Boto and Wellington, 
1988). It has been suggested that they contribute to the support of coastal marine communities (Odum and Heald, 1975; Odum et al., 1982). Mangroves may also act as sinks for carbon, nitrogen and phosphorus (Nedwell, 1975; Odum et al., 1982).

However, little information is available about soil characteristics of mangrove ecosystems (Walsh, 1974). In comprehensive studies, pedological items have only been touched (Clough, 1979; Day et al., 1987). Pedological studies have concentrated on the development to acid sulfate soils (ASS) (Pons, 1973; Dent, 1980, 1986), geo-microbiological ones on the turnover of catrbon, nitrogen and sulfur (Nedwell et al., 1994; Kristensen et al., 1994). The present work was undertaken to investigate general physical and chemical properties of soils occurring within the Balandra mangrove. Because mangroves can be described as the tropical equivalent to the saltmarsh (Walsh, 1974), the Balandra soils are compared with soils of typical saltmarsh of the North Sea coast. Those saltmarsh soils mostly show a clayey or silty texture, low bulk densities (< $1 \mathrm{~g} \mathrm{~cm}^{-3}$ ), saline and neutral conditions (8-25 $\mathrm{g}^{-1}$ and $\mathrm{pH} 7$, respectively), 50-110 $\mathrm{g} \mathrm{kg}^{-1}$ carbonate, mostly 10-40 $\mathrm{g} \mathrm{kg}^{-1}$ organic carbon and $1-10 \mathrm{~g} \mathrm{~kg}^{-1}$ sulfur (Giani, 1992). As many tropical intertidal soils develop to ASS (Ponamperuma, 1972), it was concurrently the aim of this study to search for sulfidic (potentially acid) properties in the Balandra mangrove soils. Another point of interest was methanogenesis. There are only a few investigations on methanogenesis in mangrove soils (Harriss et al., 1988; Barber et al., 1988; Bartlett et al., 1989; Sotomayor et al., 1994). It is thought to be negligible (e.g. Neue et al., 1994) as it is for typical saltmarsh soils at higher latitudes (Bartlett et al., 1985). However, saltmarsh soils built up from marine sediments and ombrogenous peat material show thousandfold higher methane concentrations than typical saltmarsh soils because of sulfate depletion (Giani, 1993), as well as methane production rates comparable to those of rice paddies (Giani et al., 1996), and concurrently develop to ASS (Giani and Giani, 1990). Tropical saltmarsh soils are also often rich in organic matter (Langenhoff, 1986) and develop to ASS (Ponamperuma, 1972). The occurrence of sulfate-depleted soils found in a Jamaican mangrove (Nedwell et al., 1994) gave rise to the investigations on methanogenesis in mangrove soils performed in this study.

\section{Material and methods}

Fluvisols of Balandra mangrove in Balandra Bay (Fig. 1), covering an area of 10 ha (Gallo et al., 1980), were investigated in spring 1995. This mangrove receives fresh water only very occasionally and is a relatively undisturbed system (Holguin et al., 1992). The sediment strategraphy in Balandra mangrove down to three or four meters consists of a Pleistocene marine coral unit, followed upwards by Holocene units which are confined to lagoonal deposits respresented by a coral debris unit, two peat strata and two silt-clay strata (Pedrin-Aviles et al., 1990). Three mangrove species were present in all stages of development: Rhizophora mangle L., red mangrove growing nearest the sea, followed by Laguncularia racemosa Gaertn., white mangrove and finally Avicennia germinans (L.) stern, black mangrove. 


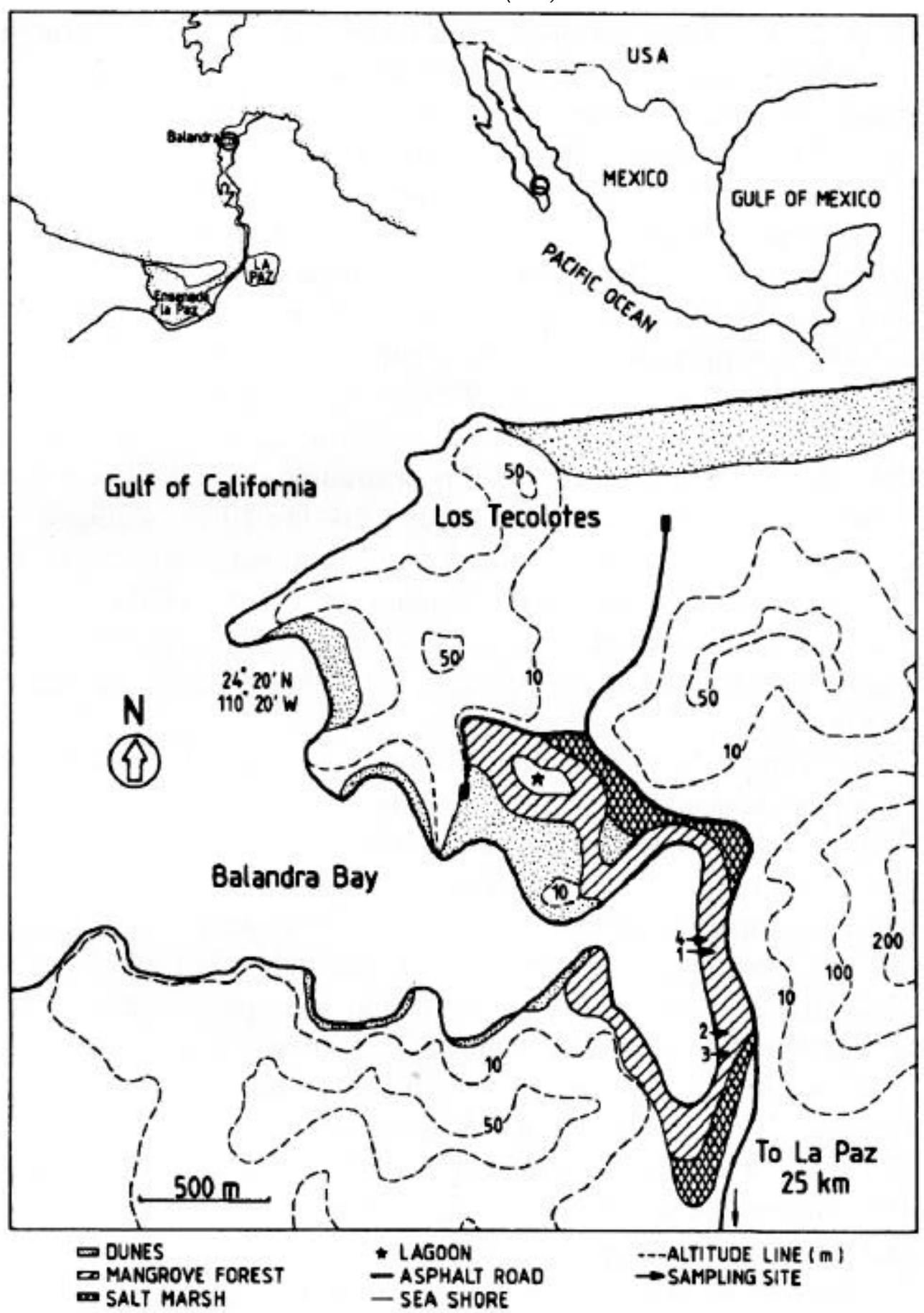

Fig. 1. Location of the sample sites on global (top right) medium (top left), and most exact (bottom) scale (modified from Holguin et al., 1992).

Samples from different sites were taken from 0-30 cm soil depth. At station 1 (Fig. 1) sampling followed a transect from sea to land. Sampling was performed in an area without vegetation (1.1), in the red mangrove (Rhizophora mangels) area (1.2) and in the black mangrove (Avicennia germinans) area (1.3). At station 2 (Fig. 1) sampling was performed in the red (2.1) and the black mangrove areas (2.2). The third station was near station 2 (Fig. 1) in a black mangrove area (3.1). The fourth sampling station (Fig. 1) was in an anthropogenically caused non vegetated area where, naturally, Avicennia germinans would occur (4.1). This site was cleared in order to get an entrance into the lagoon. Only methane data are available for this station. For comparison a fifth 
sampling, in an area without vegetation (5.1) and a black mangrove area (5.2), was performed in another mangrove within Ensenada La Paz (Fig. 1), showing impacts of pollution because of sewage effluents from the city of La Paz.

According to the FAO classification the investigated soils belong to the major soil grouping "Fluvisols". With the exception of profile 3.1 which is a "Thionic Fluvisol" on the soil unit level, all profiles are "Salic Fluvisols". According to the German classification all profiles are "Rohmarschen" on the soil type level.

A single site $(30 \mathrm{~m} \mathrm{X} 10 \mathrm{~m})$ from each mangrove zone was selected as representative of the studied soil. Sampling was performed with $100 \mathrm{ml}$ cylinders for the bulked data, for the others it was done with an auger. With each sampling three separate cores were obtained in the direct vicinity. One core was used to quantify the dissolved methane concentrations, one for methane production measurements and the last one to determine other soil properties. The soil cores were subdivided into $10 \mathrm{~cm}$ sections.

In the field duplicate samples for methane concentration measurements were immediately put into preweighed serum flasks containing $1.5 \mathrm{~N} \mathrm{NaOH}$ and sealed. After partitioning of the gaseous methane dissolved or trapped in the interstitial waters of the soil into the gas phase, the headspace was sampled with a gas-tight syringe and analyzed by gas chromatography.

For the measurements of methane production rates, duplicate samples $\left(1 \mathrm{~cm}^{-3}\right)$ of each depth interval were extruded into vacutainers and sealed under $\mathrm{N}_{2}$ atmosphere immediately after sampling. The tubes were flushed with $\mathrm{N}_{2}$ after which an initial time point was established for the time course of methane production. The tubes were incubated at room temperature $\left(25-28^{\circ} \mathrm{C}\right)$ on the following days. Every $24 \mathrm{~h}$, the headspace of the tubes was sampled with a gas-tight syringe and measured gas chromatographically. Methane accumulation in the headspace of the tubes was determined by the concentration change of methane per volume of soil in the tubes.

In situ methane flux measurements were made at stations 1 and 5 using a static chamber technique which consisted of a PVC chamber with a septum-closed serum flask at its top (12 $1^{-1}$ vol.) and an extra ring of steel. First the ring was installed (2-3 $\mathrm{cm}$ into the soil) to ensure that no gas emits when setting the chamber. The ring was filled with water and the chamber was put into the ring. Using a gas-tight syringe, aliquots $\left(10 \mathrm{~cm}^{-3}\right)$ of the chamber air were withdrawn at the beginning and at the end (after 2-3 hours) of the experiment. The samples were transferred into vacutainers by displacing distilled water inside the vacutainer for storage. Quality control checks revealed that the vacutainers did not leak an appreciable amount of methane in 3 days, but samples were analyzed in the laboratory on the day after returning from the field.

Duplicate samples for the other measurements were put into polyethylene bags under NZ atmosphere. The tightly closed bags were immediately taken to the laboratory. After measurement of redox potential and $\mathrm{pH}$, one portion of the samples was centrifuged The porewater obtained was used for sulfate, salinity and cation measurements. Another portion was air dried and used for other measurements.

- Grain size distribution - after $\mathrm{HCl}$ and $\mathrm{H}_{2} \mathrm{O}_{2}$ treatment and dispersing particles $<2$ $\mathrm{mm}$ by shaking in sodium polyphosphate solution using sieves and Atterberg cylinders.

- Volume data - gravimetrically and by weight loss on evaporation at $105^{\circ} \mathrm{C}$. 
- Redox potential - by $\mathrm{Pt}-\mathrm{Ag} / \mathrm{AgCl}$ electrode, referenced to a hydrogen electrode at $25^{\circ} \mathrm{C}$. The determination upon reaching equilibrium was in triplicate.

- Porewater - by centrifugation.

- Salinity - by hand refractometer (0-10 g/100 g) (Krüss 4 RN 32).

- Sulfate -turbidometrically according to Kempf and Andres (1977).

- $\mathrm{pH}$ - electrometrical measurement with a glass electrode.

- Carbonate - with a Scheibler apparatus.

- Carbon and nitrogen - by C/N analyzer (Carlo Erba 1500) after grinding.

- Phosphorus - after ignition and $\mathrm{HNO}_{3}$ treatment, photometrical measurement tinged with vanadate-molybdate reagent.

- Pyrite - $\mathrm{HNO}_{3} / \mathrm{HCl}$ treatment according to Howarth and Merkel (1984) and sulfate determination.

- Exchangeable and water soluble cations - shaking threefold in $0.1 \mathrm{M} \mathrm{SrC1} 1_{2}$ solution (soil/solution ratio: $1 / 4$ ), spectrometrical measurement in AAS (Varian SpectrAA 300).

- Methane - determination by direct injection of $0.4 \mathrm{~cm}^{-3}$ sample into a Varian "vista series" gas chromatograph equipped with a flame ionization detector and a Hewlett-Packard silica capillary column (ID: $0.32 \mathrm{~mm}$; length: $50 \mathrm{~m}$ ) maintained at $70^{\circ} \mathrm{C}$. Carrier gas was nitrogen and the flow rate was $7 \mathrm{~cm}^{-3} \mathrm{~min}^{-1}$. Injector and detector temperature were set at $250^{\circ} \mathrm{C}$. Sample peaks (recorded on LKB Bromma 2210) were compared to commercial preparations of 10 to 100 ppmv methane standards. The largest variation among methane standards was within $10 \%$. The standard error of the mean was less than $30 \%$.

\section{Results}

Full analytical data are given in Table 1 and salient points are highlighted below.

The grain size distribution was dominated by the silt fraction. Profiles of station 5 showed higher bulk densities $\left(1.4\right.$ and $\left.1.5 \mathrm{~g} \mathrm{~cm}^{-3}\right)$ and lower water contents $\left(293\right.$ and $\left.385 \mathrm{ml} \mathrm{1}^{-1}\right)$ than the other stations. According to the different elevations above sea level, the lowest profiles without vegetation $(1.1,5.1)$ showed the lowest air content $\left(38\right.$ and $\left.50 \mathrm{ml} \mathrm{l}^{-1}\right)$ followed by the red mangrove profiles $(1.2,2.1)$ and then with values up to $207 \mathrm{ml}^{-1}$ by the highest black mangrove profiles.

Red mangrove profiles showed the lowest, and black mangrove profiles the highest redox potentials. Redox potentials mostly increased with increasing soil depths. All profiles were saline and neutral. However, after peroxide treatment $\mathrm{pH}$ dropped dramatically to $\mathrm{pH}<2.5$ in the profile 3.1, and also in one section of profile 1.2. All profiles contained carbonate. Lowest contents (1.9-5.8 $\mathrm{g} \mathrm{kg}^{-1}$ ) occurred in the profiles 2.1 and 3.1, which showed the most striking $\mathrm{pH}$ drop. Soils of station 1 were the richest in carbonate with more than $200 \mathrm{~g} \mathrm{~kg}^{-1}$ but with values decreasing with depth in the red and black mangrove area.

The $\mathrm{C}_{\text {org }}$ content varied in a wide range between $<2$ and $139 \mathrm{~g} \mathrm{~kg}^{-1}$. Even more than $400 \mathrm{~g} \mathrm{~kg}^{-1}$ $\mathrm{C}_{\mathrm{org}}$ was found in soils north of station 1 (data not shown), clearly showing peaty conditions. The nitrogen contents were $<0.3-5.7 \mathrm{~g} \mathrm{~kg}^{-1}$, the $\mathrm{C} / \mathrm{N}$ ratios $8-39$. The phosphorus content of the soils 


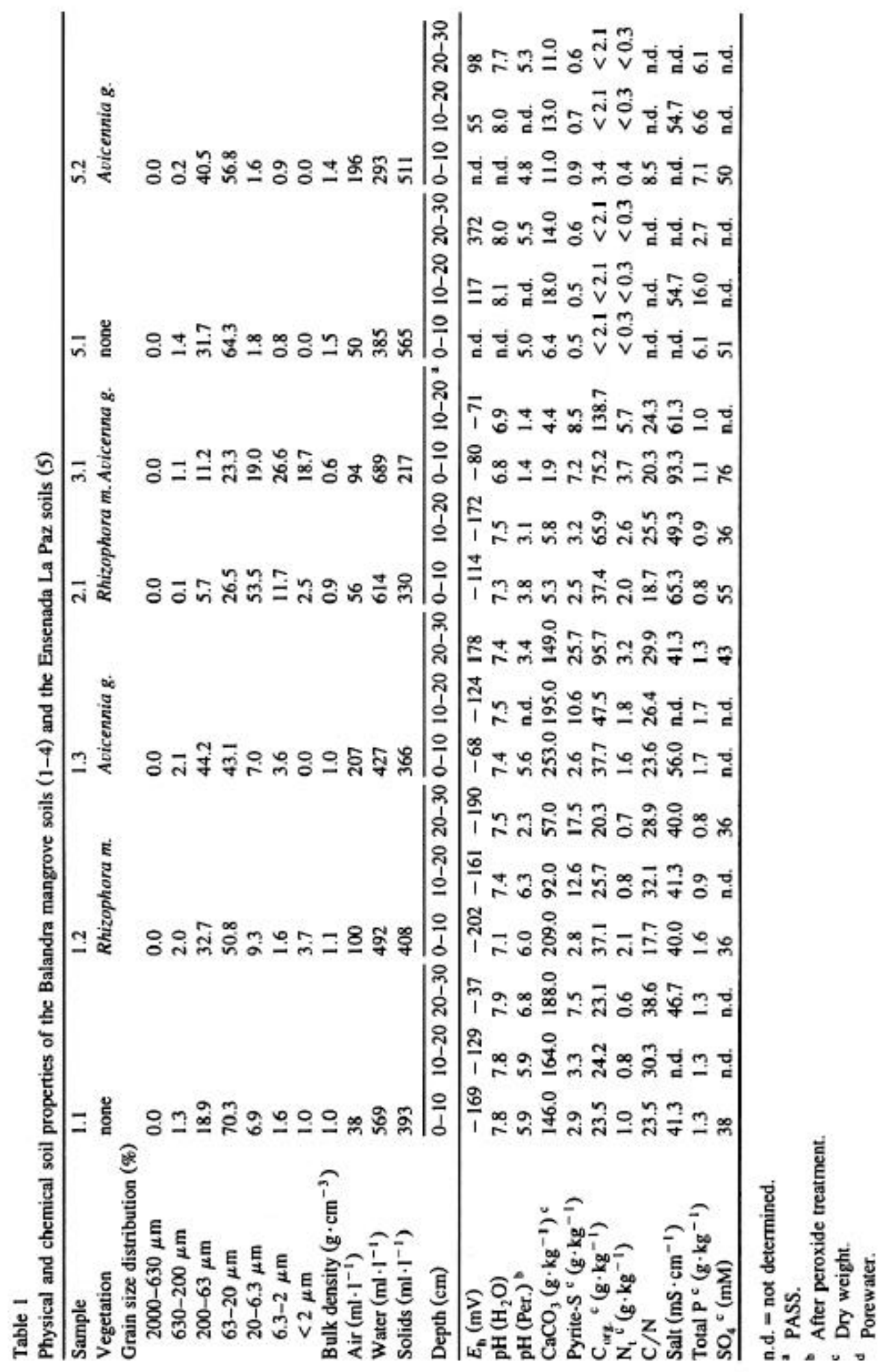


Table 2

Absolute contents and relative distribution of exchangeable and water soluble cations of the Balandra mangrove soils (1-4) and the Ensenada La Paz soils (5)

\begin{tabular}{|c|c|c|c|c|c|c|c|c|c|c|}
\hline \multirow[t]{3}{*}{ Sample } & \multirow{3}{*}{$\begin{array}{l}\text { Depth } \\
(\mathrm{cm})\end{array}$} & \multirow{2}{*}{\multicolumn{5}{|c|}{$\begin{array}{l}\text { Exchangeable and water soluble cations } \\
\left(\mathrm{mmol} \mathrm{eq}-\mathrm{kg}^{-1}\right)^{\mathrm{a}}\end{array}$}} & \multicolumn{4}{|c|}{ Relative distribution (\%) } \\
\hline & & & & & & & \multirow[t]{2}{*}{$\mathrm{Ca}^{2}$} & \multirow[t]{2}{*}{$\mathrm{Mg}^{2+}$} & \multirow[t]{2}{*}{$\mathrm{Na}^{+}$} & \multirow[t]{2}{*}{$\mathrm{K}$} \\
\hline & & $\mathrm{Ca}^{2+}$ & $\mathrm{Mg}^{2+}$ & $\mathrm{Na}^{+}$ & $\mathrm{K}^{+}$ & $\mathrm{CEC}$ & & & & \\
\hline \multirow[t]{3}{*}{1.1} & $0-10$ & 139 & 127 & 03 & 17 & 182 & 29 & 26 & 42 & 4 \\
\hline & $10-20$ & 160 & 133 & 184 & 17 & 184 & 32 & 27 & 37 & 3 \\
\hline & $20-30$ & 173 & 140 & 204 & 22 & 272 & 32 & 26 & 28 & 4 \\
\hline \multirow[t]{3}{*}{1.2} & $0-10$ & 159 & 138 & 251 & 19 & 176 & 28 & 24 & 44 & 3 \\
\hline & $10-20$ & 213 & 185 & 279 & 24 & 365 & 30 & 26 & 40 & 3 \\
\hline & $20-30$ & 214 & 197 & 247 & 26 & 403 & 31 & 29 & 36 & 4 \\
\hline \multirow[t]{3}{*}{1.3} & $0-10$ & 156 & 173 & 282 & 20 & 223 & 25 & 27 & 45 & 3 \\
\hline & $10-20$ & 236 & 358 & 623 & 28 & 448 & 19 & 29 & 50 & 2 \\
\hline & $20-30$ & 343 & 476 & 875 & 39 & 578 & 20 & 28 & 51 & 2 \\
\hline \multirow[t]{2}{*}{2.1} & $0-10$ & 203 & 341 & 483 & 27 & 331 & 19 & 32 & 46 & 3 \\
\hline & $10-20$ & 173 & 341 & 455 & 28 & 339 & 17 & 34 & 46 & 3 \\
\hline \multirow[t]{2}{*}{3.1} & $0-10$ & 256 & 683 & 1099 & 48 & 581 & 12 & 33 & 53 & 2 \\
\hline & $10-20$ & 309 & 818 & 1195 & 55 & 544 & 13 & 34 & 50 & 2 \\
\hline \multirow[t]{3}{*}{5.1} & $0-10$ & 56 & 95 & 235 & 16 & 137 & 14 & 24 & 59 & 4 \\
\hline & $10-20$ & 55 & 72 & 143 & 15 & 133 & 19 & 25 & 50 & 5 \\
\hline & $20-30$ & 81 & 110 & 298 & 19 & 151 & 16 & 22 & 59 & 4 \\
\hline \multirow[t]{3}{*}{5.2} & $0-10$ & 69 & 150 & 335 & 19 & 144 & 12 & 26 & 59 & 3 \\
\hline & $10-20$ & 61 & 93 & 237 & 18 & 150 & 15 & 23 & 58 & 4 \\
\hline & $20-30$ & 45 & 90 & 212 & 17 & 140 & 12 & 25 & 58 & 5 \\
\hline
\end{tabular}

${ }^{a}$ Dry weight.

investigated at Balandra mangrove was mostly $0.8-1.7 \mathrm{~g} \mathrm{~kg}^{-1}$ but distinctly higher phosphorus concentrations, up to $16 \mathrm{~g} \mathrm{~kg}^{-1}$, occurred in the soils $(5.1,5.2)$ of the mangrove of Ensenada $\mathrm{La}$ Paz.

The relative distribution of the main cations of the porewater determined for the Balandra profiles always was $74 \% \mathrm{Na}, 17 \% \mathrm{Mg}, 6 \% \mathrm{Ca}$ and $3 \% \mathrm{~K}$. The fraction of exchangeable and water soluble cations (mobile cations) also showed values decreasing in the order $\mathrm{Na}>\mathrm{Mg}>\mathrm{Ca}>\mathrm{K}$. However, the Na-concentrations were smaller (28-59\%) and the concentrations of $\mathrm{Mg}(22-34 \%)$, $\mathrm{Ca}(12-32 \%)$ higher than those of the porewater (Table 2). Following the transect from 1.1 to 1.3 from sea to land, the profiles showed decrasing $\mathrm{Ca}$ - and increasing Na-concentrations.

The profiles of station 5 showed the lowest pyrite contents $\left(<1 \mathrm{~g} \mathrm{~kg}^{-1}\right)$. Highest contents $(3-26$ $\mathrm{g} \mathrm{kg}^{-1}$ ) with increasing values with increasing soil depth were found at station 1 . The sulfate concentrations of the porewater were beween 36 and $76 \mathrm{mM}$, thus showing no sulfate depletion.

The methane concentrations of the soils mostly were lower than $2 \mu \mathrm{M}$ (Table 3). In some profiles and soil sections the methane concentration even was below the limit of 
Table 3

Methane concentration and methane production rates of the Balandra mangrove soils (1-4) and the Ensenad

La Paz soils (5)

Table 3

Methane concentration and methane production rates of the Balandra mangrove soils (1-4) and the Ensenada La Paz soils (5)

\begin{tabular}{|c|c|c|c|c|c|c|c|c|}
\hline \multirow[t]{2}{*}{ Sample } & \multirow[t]{2}{*}{ Vegetation } & \multirow[t]{2}{*}{ Depth $(\mathrm{cm})$} & \multicolumn{3}{|c|}{ Methane concentration } & \multicolumn{3}{|c|}{ Methane production rates } \\
\hline & & & $\begin{array}{l}\text { Average } \\
\left(\mu \mathrm{M} \mathrm{CH}_{4}\right)\end{array}$ & SEM $^{2}$ & $N^{b}$ & $\begin{array}{l}\text { Average } \\
\left(\mathrm{nmol} \cdot \mathrm{ml}^{-1} \cdot \mathrm{d}^{-1}\right)\end{array}$ & SEM $^{2}$ & $N^{b}$ \\
\hline \multirow[t]{3}{*}{1.1} & none & $0-10$ & $<0.2$ & nd. & 2 & 1.83 & 1.3 & 4 \\
\hline & & $10-20$ & $<0.2$ & n.d. & 2 & $<0.26$ & 0.6 & 5 \\
\hline & & $20-30$ & $<0.2$ & nd. & 2 & 1.57 & 0.9 & 6 \\
\hline \multirow[t]{3}{*}{1.2} & Rhizophora m. & $0-10$ & 2.09 & 2.2 & 2 & 7.62 & 4.9 & 8 \\
\hline & & $10-20$ & 1.55 & 0.1 & 2 & 2.49 & 2.4 & 5 \\
\hline & & $20-30$ & 1.90 & 0.6 & 2 & $<0.26$ & 0.6 & 5 \\
\hline \multirow[t]{3}{*}{1.3} & Avicenna g. & $0-10$ & $<0.2$ & n.d. & 2 & 23.3 & 17.7 & 8 \\
\hline & & $10-20$ & $<0.2$ & n.d. & 2 & 1.84 & 2.6 & 5 \\
\hline & & $20-30$ & $<0.2$ & n.d. & 2 & 1.45 & 0.2 & 2 \\
\hline \multirow[t]{2}{*}{2.1} & Rhizophora m. & $0-10$ & 1.14 & n.d. & 1 & n.d. & n.d. & n.d. \\
\hline & & $10-20$ & n.d. & n.d. & n.d. & n.d. & n.d. & n.d. \\
\hline \multirow[t]{2}{*}{2.2} & Avicennia g. & $0-10$ & 0.43 & n.d. & 1 & 1.25 & 0.4 & 4 \\
\hline & & $10-20$ & 0.37 & n.d. & 1 & 1.05 & 0.8 & 4 \\
\hline \multirow[t]{2}{*}{3.1} & Avicenna g. & $0-10$ & 0.72 & n.d. & 1 & 0.56 & 0.5 & 4 \\
\hline & & $10-20$ & n.d. & n.d. & n.d. & n.d. & nd. & n.d. \\
\hline 4.1 & none & $0-10$ & 33.1 & n.d. & 1 & 97.5 & 41.5 & 3 \\
\hline \multirow[t]{3}{*}{5.1} & none & $0-10$ & 0.48 & 0.1 & 3 & n.d. & nd. & n.d. \\
\hline & & $10-20$ & 0.57 & 0.2 & 3 & n.d. & n.d. & n.d. \\
\hline & & $20-30$ & 0.74 & 0.1 & 2 & n.d. & n.d. & n.d. \\
\hline \multirow[t]{3}{*}{5.2} & Avicennia g. & $0-10$ & 0.51 & 0.3 & 3 & 2.03 & 1.1 & 4 \\
\hline & & $10-20$ & 0.57 & 0.3 & 3 & n.d. & n.d. & n.d. \\
\hline & & $20-30$ & 0.64 & 0.1 & 2 & n.d. & n.d. & n.d. \\
\hline
\end{tabular}

detection. Only the soil of station 4 showed much higher values with $33 \mu \mathrm{M}$. Methan production rates showed a similar pattern with values between 1 and $23 \mathrm{nmol} \mathrm{ml}^{-1} \mathrm{~d}^{-1}$ except at station 4 . There the methane production rate was $100 \mathrm{nmol} \mathrm{ml}^{-1} \mathrm{~d}^{-1}$. Methane emissions were not detectable. This was also true for experiments in which gas domes covered the pneumatophores of Auicennia germinans.

\section{Discussion}

\subsection{Soil characteristics}

Some properties of the Balandra mangrove soils - high variability in texture absence of the coarse sand fraction, negative redox potentials, low air volumes, neutral $\mathrm{pH}$ reactions, saline 
conditions, the relative cation distribution of the porewater and the occurrence of carbonate and pyrite - are comparable with those of saltmarshes of the North Sea coast (Brümmer, 1968; Giani, 1992). However, the variability and the amount of salt, phosphorus, carbonate, pyrite, $\mathrm{C} / \mathrm{N}$ ratios and organic carbon are higher in the mangrove soils investigated.

The high variability in texture and organic matter of the Balandra soils poses a difficulty for classification in that, within one mangrove system, several types of mangrove can occur, which are classified as reef, sand, mud and peat type (Chapman, 1940 and Rutzler, 1969 in: Walsh, 1974). In all mangrove types found in Balandra the same vegetation zonation occurred.

In contrast to saltmarsh soils of the North Sea coast, where the Na-concentrations of the mobile cations decrease from 67 to $47 \%$ and the Ca-concentrations increase from 11 to $22 \%$ in the transect from sea to land as a consequence of salt leaching and carbonate solving (Giani et al., 1993), the Balandra soils show increasing Na-concentrations from nearly 40 to $50 \%$ and decreasing Ca-concentrations from 30 to $50 \%$. This may be attributed to the increasing accumulation of salts from sea to land in the Balandra mangrove. Since salt accumulation by evaporation is often caused by arid conditions, it is characteristic of mangroves - like Balandra - at the border of subtropical and arid climates. For many mangroves, increasing freshwater influence is described (Walsh, 1974), as a floristic consequence Avicennia germinans is found nearest to the sea (Alongi, 1989). In Balandra Avicennia germinans was found in a belt closing the mangrove swamp landwards. The increasing Na-concentration of the mobile cations in the transect from sea to land also indicates the further soil succession. Adjacent to the mangroves a strongly saline zone of saltmarsh occurs, carrying sparse Salicornia shrubs.

\subsection{Potential acid sulfate soil (PASS) properties}

PASS are indicated by a sulfur (pyrite) content higher than $7.5 \mathrm{~g} \mathrm{~kg}^{-1}$, a less than threefold amount of carbonate and a pH drop after peroxide treatment to 2.5 or less (Dent, 1986). Profile 3.1 shows these properties, thus it is a PASS, whereas profile 1.2 is not, although one section also shows a $\mathrm{pH}$ value less than 2.5 after peroxide treatment, obviously caused by incomplete dissolution of carbonate during peroxide treatment.

Nevertheless, the possibility of ASS development is given in Balandra mangrove, whereas it is not in typical temperate saltmarsh soils (Giani, 1992). In marine semi-terrestrial soils an intensive or long-term sulfur accumulation leads to PASS. High amounts of organic matter are necessary for this. Some Balandra soils have as much or even more organic matter than humus rich saltmarsh soils of the North Sea coast that developing to ASS (Giani and Giani, 1990). The following aspects however, suggest a long-term ASS developing process in Balandra mangrove soils: (i) Mineralisation rates are often low in mangrove ecosystems (Nedwell et al., 1994; Kristensen et al., 1994). (ii) In Balandra soils highest pyrite contents did not correlate with highest $\mathrm{C}_{\text {org }}$ contents. (iii) No sulfate depletion was found. (iv) No high methane concentrations occured. As stated for other mangrove ecosystems (Walsh, 1974), Balandra soils showed a tendency of humus accumulation with $\mathrm{C}_{\text {org }}$ contents up to more than $400 \mathrm{~g} \mathrm{~kg}^{-1}$, raising the question about the reason for the high $\mathrm{C}_{\text {org }}$ variability within one mangrove system and the role of mangrove soils as a carbon sink and their general role within the global carbon cycle. 


\subsection{Methanogenesis}

Generally, rates of methane production in Balandra soils were 1 to $23 \mathrm{nmol} \mathrm{ml}^{-1} \mathrm{~d}^{-1}$. Highest rates in the topsoil samples might be attributed to a subsurface pool $\mathrm{c}$ labile carbon, as found in the top of Jamaican mangrove soils (Nedwell et al., 1994 Overall the values are similar to those found for other marine mangroves investigated so far (Sotomayor et al., 1994), but considerably higher than those found for marine surfae sediments and saltmarsh soils of higher latitudes, in which methane production rates of less than $1 \mathrm{nmol} \mathrm{ml}^{-2} \mathrm{~d}^{-1}$ have been measured (Warford et al., 1979; Senior et al 1982).

In spite of higher rates of methane production, methane concentrations were low ar similar to those found e.g. in typical saltmarsh soils at the North Sea coast (Giani et al 1996). Moreover, methane emission was not detected. This indicates, that methanogenisis is balanced by anaerobic or aerobic methane oxidation processes. A high oxidatic potential is likely for the Balandra soils, caused by intensive crab bioturbation, typical of mangrove soils (e.g. Kristensen et al., 1994). This result differs from that of Sotomay or et al. (1994) who found higher methane concentrations and emission of methane but similar production rates in Puerto Rico mangrove soils. Thus, low methane concentr tions do not indicate low rates of methanogenesis (Rudd and Taylor, 1980) but might be an indicator of low methane release and/or balance between methanogenesis at methane oxidation.

The considerable methanogenesis may be attributed to the higher amounts noncompetitive substrates (e.g. methylated amines, DMS; King, 1984) - used by methanogenic bacteria but not by sulfate reducers (King, 1984) - in mangrove soils compared with typical saltmarsh soils of higher latitudes. As their distribution al availability are controlled by the biomass of organisms containing these compounds (King, 1984), crabs occurring in high populations in Balandra mangrove soils might be source of these noncompetitive substrates (Yancey et al., 1982). Because of the high sulfate content and its conservative behaviour, methanogenesis based on competitive substrates $\left(\mathrm{H}_{2} / \mathrm{CO}_{2}\right.$, acetate $)$ is unlikely.

Methane increase in the atmosphere plays an important role for greenhouse warmi (Aselmann and Crutzen, 1990). Though the few investigations on methanogenesis mangrove soils so far available do not indicate that mangrove soils contribute signicantly to the global atmospheric methane increase, anthropogenic disturbance of the ecosystems might change the situation dramatically. Indications were obtained by Sotomayor et al. (1994) who found that freshwater and nutrient supply leads to increased loss of methane to the atmosphere. Our study showed that methane concentrations more than $33 \mu \mathrm{M}$ and methane production rates ten fold higher than those normally found occur even under marine conditions. These higher concentrations and production rates of methane are probably caused by a reduced oxidation potential of this cleared site. The destruction of vegetation leads to the fact that no oxygen is brought into the soil by the specialized root system. In contrast to the other soils investigated in Balandra mangrove, profile 4.1 showed reduced morphological features near the surface. Thus, the potential of mangrove soils to emit methane to the atmosphere seems to be high case of anthropogenic impact. The wide distribution of mangrove ecosystems and the 
rapidly increasing use for shrimp and clam aquaculture recommend further research on the sensitivity of these ecosystems with respect to methanogenesis.

\section{Acknowledgements}

This work was supported by the grant Gi-171/5-1 of the Deutsche Forschungsges ellschaft and by grant \# 3541-A from Consejo Nacional de Ciencia y Tecnologia (CONACyT), Mexico. We thank Mr. Gerardo Toledo for helping in field sampling and Mr. Ariel Cruz for technical help.

We thank Lic. Laura Pimentel, subdelegada de Ecologia, Secretaria de Medio Ambiente Recursos Naturales y Pesca, Delegacion del estado de Baja California Sur for granting us part of Balandra lagoon as an experimental field.

\section{References}

Alongi, D.M., 1989. The role of soft-bottom benthic communities in tropical mangrove and coral reef ecosystems. Rev. Aquat. Sci., 1: 243-280.

Aselmann, J. and Crutzen, P.J., 1990. A global inventary of wetlands distribution and seasonality, net primary productivity and estimated methane emissions. In: A.F. Bouwman (Editor), Soils and the Greenhouse Effect. Wiley, Chichester, pp. 441-449.

Barber, T.R., Burke, R.A. and Sackett, W.M., 1988. Diffusive flux of methane from warm wetlands. Glob. Biogeochem. Cycles, 2: 411-425.

Bartlett, K.B., Harriss, R.C. and Sebacher, D.L., 1985. Methane flux from coastal salt marshes. J. Geophys. Res., 90: 5710-5720.

Bartlett, D.S., Bartlett, K.B., Hartman, J.M., Harriss, R.C., Sebacher, D.I., Pelletier-Travis, R., Dow,D.D. and Brannon, D.P., 1989. Methane emissions from the Florida Everglades: Pattern of variability in a regional wetland ecosystem. Glob. Biogeochem. Cycles, 3: 363-374.

Boto, K.G. and Wellington, J.T., 1988. Seasonal variations in concentrations and fluxes of dissolved organic and inorganic material in a tropical, tidally dominated, mangrove waterway. Mar. Ecol. Prog. Ser., 50: 151-160.

Brümmer, G., 1968. Untersuchungen zur Genese von Marschen. Dissertation, C.A. Universität, Kiel.

Clough, B.F., 1979. Mangrove ecosystems in Australia: structure, function and management. Colorcraft Ltd., Hongkong.

Day, J.W. jr., Hall, C.A.S., Kemp, W.M. and Yanez-Arancibia, A., 1987. Intertidal Wetlands: Saltmarshes and Mangrove Swamps. Wiley, New York.

Dent, D., 1980. Acid sulphate soils: morphology and prediction. J. Soil Sci., 31: 87-99.

Dent, D.L., 1986. Acid sulphate soils: a baseline for research and development. Publ. 3e, Int. Inst. Land Reclamation and Development, Wageningen, $204 \mathrm{pp}$.

Dye, A.H. and Lasiak, T.A., 1986. Microbenthos, meiobenthos and fiddler crabs: trophic interactions in a tropical mangrove sediment. Mar. Ecol. Prog. Ser., 32: 259-264.

Gallo, J.P., Maeda, A. and Maravilla, O., 1980. Mangrove systems of The Bay of La Paz as exploitable resources. In: Memories 2th Int. Workshop on Biosalinity, La Paz, B.C.S. Mexico. Plenum Press.

Giani, L., 1992. Entwicklung and Eigenschaften von Marschböden im Deichvorland der südlichen Nordseeküste. Habilitat, C.v.O. University, Oldenburg.

Giani, L., 1993. Potential acid sulphate soils developed in marine and highmoor peat materials. In: D.L. Dent and M.E.F. van Mensvoort (Editors), Selected papers of the Ho Chi Minh City Symposium on ASS. Publ. 53, ILRI Press, Wageningen, pp. 81-88.

Giani, L. and Giani, D., 1990. Characteristics of a marshland soil built up from marine and peat material. Geoderma, 47: 151-157. 
Giani, L., Keuchel, B., Nay, M. and Widzgowsky, S., 1993. Periodische and aperiodische Veränderungen ii den Eigenschaften junger Marschböden im Deichvorland. Z. Pflanzenemähr. Bodenkd., 156: 323-331.

Giani, L., Dittrich, K., Martsfeld-Hartmann, A. and Peters, G., 1996. Methanogenesis in typical saltmarsh soil (Salic Fluvisols) and humus-rich saltmarsh soils (Thionic Fluvisols) of the southern North Sea coast. Eui J. Soil Sci., in press.

Harriss, R.C., Sebacher, D.I., Bartlett, K.B., Bartlett, D.S. and Crill, P.M., 1988. Sources of atmospheri methane in the South Florida environment. Glob. Biogeochem. Cycles, 2: 231-243.

Holguin, G., Guzman, M.A. and Bashan, Y., 1992. Two new nitrogen fixing bacteria from the rhizosphere c mangrove trees: Their isolation, identification and in vitro interaction with rizosphere Staphylococcus sp FEMS Microbiol. Ecol., 101: 207-216.

Howarth, R.W. and Merkel, S., 1984. Pyrite formation and the measurement of sulfate reduction in saltmars sediments. Limnol. Oceanogr., 29: 598-608.

Kempf, T. and Andres, K.F., 1977. Die Automatisierung von Analyseverfahren für die Bestimmung vo Boraten, Sulfaten and Nitraten in Wasserproben. Z. Chem. Labor Betrieb, 28: 229-232.

King, G.M., 1984. Utilization of hydrogen, acetate and "noncompetitive" substrates by methanogenic bacteri in marine sediments. Geomicrobiol. J., 3: 295-306.

Kristensen, E., King, G.M., Holmer, M., Banta, G.T. Jensen, M.H. Hansen, K. and Bussarawit, N., 199, Sulfate reduction, acetate turnover and carbon metabolism in sediments of the Ao Nam Bor mangrove Phyket, Thailand. Mar. Ecol. Prog. Ser., 109: 245-255.

Langenhoff R., 1986. Distribution, mapping, classification and use of Acid Sulfate Soils in the tropics. Stenc nr. 6978, Soil Survey Institute (STIBOKA), Wageningen, pp. 1-139.

Nedwell, D.B., 1975. Inorganic nitrogen metabolism in a eutrophicated tropical mangrove estuary. Water Res 9: 221-231.

Nedwell, D.B., Blackburn, T.H. and Wiebe, W.J., 1994. Dynamics and nature of the turnover of organ carbon, nitrogen and sulfur in the sediments of a Jamaican mangrove forest. Mar. Ecol. Prog. Set., 111 223-231.

Neue, H.V., Gaunt, JL., Wang, Z.P., Becker-Heidmann, P. and Quijano, C., 1994. Carbon in tropic wetlands. Trans. 15th World Congr. Soil Sci., Acapulco, Vol. 9, pp. 201-220.

Odum, W.E. and Heald, E.J., 1975. The detritus-band foodweb on an estuarine mangrove community. In: L.1 Cromin (Editor), Estuarine Research. Academic Press, New York, pp. 265-286.

Odum, W.E., McIner, C.C. and Smith, T.J., 1982. The ecology of the mangroves of south Florida: community profile. U.S. Fish and Wildlife Serv., Off. Biol. Serv., Washington, DC, FWS/OBS-81/2

Pedrin-Avilés, S., Padilla-Arredondo, G., Diaz-Rivera, E., Sirkin, L. and Stuckenrath, R., 1990. Estratigral del Pleistoceno Superior-Holoceno en el Area de la Laguna costera de Balandra, estado de Baja Californ Sur. Universidad Nacional Autonoma de Mexico, Rev. Inst. Geol., 9: 170-176.

Ponamperuma, F.N., 1972. The chemistry of submerged soils. Adv. Agron., 24: 29-96.

Pons, L.J., 1973. Outline of genesis, characteristics, classification and improvement of acid sulfate soils. In: 1 Dost (Editor), Proc. Int. Symp. Acid Sulfate Soils, Wageningen, ILRI-publ. 18.

Robertson, A.J., 1986. Leaf-burying crabs: their influence on energy flow and export from mixed mangro forest (Rhizophora spp. ) in northeastern Australia. J. Exp. Mar. Biol. Ecol., 102: 237-248.

Rudd, JW.M., Taylor, C.D., 1980. Methane cycling in aqatic environments. Adv. Aquat. Microbiol., 77-150.

Senior, E., Lindström, B., Banat, J.M. and Nedwell, D.B., 1982. Sulfate reduction and methanogenesis in t sediment of a saltmarsh on the east coast of the U.K.. Appl. Environ. Microbiol., 43: 987-996.

Sotomayor, D., Corredor, J.E. and Morell, 1.M., 1994. Methane flux from mangrove sediments along t southeastern coast of Puerto Rico. Estuaries, 17: 140-147.

Twilley, R.R., 1985. The exchange of organic carbon in basin mangrove forests on a southwest Flori estuary. Estuar. Coast. Shelf Sci., 20: 543-447.

Walsh, G.E., 1974. Mangroves: a review. In: R.J. Reimold and W.H. Queen (Edsitors), Ecology Halophytes. Academic Press, New York, pp. 51-174.

Warford, A.L., Kosiur, D.R., Doose, P.R., 1979. Methane production in Santa Barbara basin sedimen Geomicobiol. J., 1: 117-137.

Yancey, P.H., Clark, ME., Hand, S.C., Bowlus, R.D. and Somera, G.N., 1982. Living with water stre evolution of osmolyte systems. Science, 217: 1214-1222. 